\title{
A Brief Analysis and Suggestions on the Current Situation of New En- ergy Vehicles in China
}

Tianzuo Guan*

Northeast Normal University, Changchun 130024, Jilin province, China. E-mail: 1169646913@qq.com

Abstract: With continuous development of China's economy in the past two decades, people's living conditions have been greatly improved. The improved living quality boosts the prosperity of the automobile industry in China. However, whilst the popularity of automobiles promotes the rapid development of social economy and modern civilization, it also brings severe energy and environmental problems.

The government pays great attention to these problems, and promotes the development of new energy vehicle industry by issuing various policies and encouraging consumers to actively buy new energy vehicles. However, under these policy incentives and economic incentives, the domestic new energy vehicle industry did not present the expected market response.

This paper briefly describes the development status and existing problems of domestic new energy vehicle industry, and puts forward some feasible suggestions.

Keywords: New Energy Vehicles; Existing Problems; Suggestions

\section{Advantages of electric vehicles}

\subsection{Energy saving}

EVs can directly reduce the consumption of fossil energy, so as to extend the service span of these non-renewable energy resources, and greatly promote the sustainable development of such resources. Although the electricity produced in China still mainly derives from thermal power generation, the hydropower generation, nuclear energy, wind energy and solar power generation in 2020 rose by $5.3 \%, 5.1 \%, 10.5 \%$ and $8.5 \%$ respectively compared with that in 2019 . And these four kinds of energy accounted for $28.8 \%$ of the total annual power generation ${ }^{[1]}$. With the gradual transfer of domestic power generation sources, EVs can truly realize the new energy vehicles.

\subsection{Environmental protection}

According to a research, $93 \%$ of carbon dioxide emission in Iran is caused by road transportation ${ }^{[2]}$, and $27 \%$ of carbon emission in the United States comes from transport sector ${ }^{[3]}$. On the contrary, an electric vehicle will merely produce emissions of $70 \mathrm{~g} \mathrm{CO}_{2} \mathrm{e} / \mathrm{km}$ through its lifetime ${ }^{[4]}$, which is remarkably lower than the current EU requirement $-95 \mathrm{~g} \mathrm{CO}_{2} \mathrm{e} / \mathrm{km}$. Indeed, this figure will get further reduced along with the technology improvement in EVs. Meanwhile, EVs can eventually realize zero pollution as long as the batteries are properly disposed. If inner combustion engine vehicles are replaced by EVs on urban roads, the exhaust pollution and greenhouse gas problems in the city area will be greatly improved. For example, the option of EVs is expected to annually reduce $24.8 \%$ of the air pollutant emission in

This is an open-access article distributed under the terms of the Creative Commons Attribution Non-Commercial License (http://creativecommons.org/licenses/by-nc/4.0/), which permits unrestricted non-commercial use, distribution, and reproduction in any medium, provided the original work is properly cited. 
Delhi $^{[5]}$.

\subsection{Comfort}

Because there is no internal combustion engine or because EVs do not mainly rely on internal combustion engine, EVs are free from the roar compared with traditional cars during driving, which greatly improves the demand of passengers for quietness. At the same time, after the cancellation of internal combustion engine, EVs have a relatively more obvious advantage in wheelbase. Automobile manufacturers can further adjust the layout of the car reasonably to create more space for passengers.

\subsection{Other advantages}

\subsubsection{Economic saving}

At present, the government gives certain subsidies to new energy vehicle buyers, and the policy in 2018 was to subsidize 10,000-50,000 yuan (according to the mileage); at the same time, consumers do not need to pay vehicle purchase tax (the tax rate is $10 \%$ ) for EVs that meet the requirements. The combined subsidies of these two parts can reach up to 120,000 yuan, which is very attractive to many consumers.

The average energy consumption per $100 \mathrm{~km}$ of EVs is $16 \mathrm{kwh}$. Calculating the civil electricity consumption at 0.4 yuan $/ \mathrm{kWh}$, the driving cost of EVs per $100 \mathrm{~km}$ is 6.4 yuan. For fuel vehicles with $2.0 \mathrm{~T}$ displacement, however, the actual comprehensive fuel consumption per $100 \mathrm{~km}$ is about 10.5L. Calculating the average oil price in China at 6.5 yuan/L, the cost of fuel vehicle per $100 \mathrm{~km}$ is 68.3 yuan, theoretically 10 times that of EV. In this case, for households with high frequency of car usage, EVs can reduce a lot of driving costs.

\subsubsection{Easy registration procedure}

In many China metropolitans, if consumers want to buy fuel vehicles, they must meet a lot of requirements, such as years of residence and tax payment, before obtaining the purchase qualification ${ }^{[6]}$. If the residents in these cities buy EV vehicles (including hybrid vehicles), they can get their EVs registered immediately. This is definitely good news for many families with urgent vehicle usage.

\section{Overview of domestic electric vehicle development}

\subsection{Policy support from the government}

In 2009, several ministries and commissions of the Chinese government jointly initiated the development of new energy vehicles in China. Since February 2009, the Chinese government has issued a series of macro and micro policies for the development of new energy vehicles, gradually establishing and regulating the executive standards in new energy vehicle industry.

2012: new energy vehicles can be exempted from annual vehicle and vessel tax.

2013: formulate subsidy standard for fuel cell vehicle promotion for EV manufacturers: 200,000 yuan/set for passenger vehicle and 500,000 yuan/set for commercial vehicle.

2014: new energy vehicles can be exempted from vehicle purchase tax.

By June 2016, the Chinese government has issued 30 policies, covering five modules: vehicle promotion, industry regulation, charging infrastructure, enterprise directory, and industry management ${ }^{[7]}$.

These policies show that the Chinese government possesses strong determination to build a healthy, complete, and sustainable new energy vehicle industry.

\section{2 domestic and international market of new energy electric vehicle}

According to a survey conducted by Continental Group in September 2020, 86\% of Chinese respondents said they would like to buy an electric vehicle, much higher than the figure in other regions ${ }^{[8]}$.

By the end of December 2020, China has manufactured 1.46 million new energy electric vehicles. Although there is an increase of $1.5 \%$ compared with the production in 2019 , it merely accounted for $5.93 \%$ of the total annual automobile 
production - the total annual automobile production in 2020 was 24.63 million ${ }^{[1]}$.

In July 2019, the sales volume of EVs in Germany, France, and other six nations exceeded 99,000 units, increasing by $214 \%$ compared with previous year ${ }^{[9]}$.

In October 2020, specifically, Germany has sold 252530 new energy electric vehicles, accounting for $10.9 \%$ of the total vehicle sales in that month, while the data in 2019 is only $3 \%{ }^{[10]}$.

Globally, the compound annual growth rate of electric car sales from 2017 to 2023 is expected to reach $33.6 \%^{[11]}$.

It indicates that domestic consumers' expectations of new energy vehicles are not consistent with the EV market growth compared with other regions.

\section{Main factors of domestic consumers' hesitating attitude towards new en- ergy vehicles}

\section{1 policy factors}

According to the EU's carbon dioxide emission regulations, in 2021, all the passenger cars launched by car companies must meet the requirement of $95 \mathrm{~g} / \mathrm{km}$, otherwise they will face huge fines. This kind of administrative compulsory requirement is an important reason for the blowout of EVs in EU automobile market.

China has not issued a similar policy yet, and most consumers are more used to buying traditional fuel vehicles.

\subsection{Mileage of EVs}

Even if those manufacturers do not exaggerate the mileage of EVs, the actual mileage of EVs will also be affected by many objective factors: in severe cold or hot weather, air conditioning is required to work in the car, which will greatly increase power consumption and further shorten the mileage. No matter what the reason is, short mileage will weaken the evaluation from EVs users and potential users.

In fact, it is not rare for some early EV users in China to sell their EVs and then return to traditional fuel vehicles again.

\subsection{Charging factors}

Many residential areas in China, especially those over 10 years, did not plan parking spaces with charging piles, meaning that if the property department are reluctant to install charging piles for residents, EV users can only turn to the public charging station outside, which is neither economic nor convenient for EV users. Thus, many potential customers eventually give up EVs when buy a new car.

\subsection{Price factors}

Before the launch of Wuling Hongguang Mini EV, the price of domestic EV brands for passenger cars ranged from 120,000 yuan to 566,000 yuan (NiO ES8). In each price sector, there were corresponding foreign brand competitors, such as Toyota Levin, Tesla Model 3, Model Y, and Model S. The fact is, if consumers have a budget over 300,000 yuan, they have a great number of choices from fuel vehicles besides electric vehicles. After all, some consumers may consider not only cost performance but also other factors, such as brand premium.

What's more, after Tesla's China factory put into production in 2020, the price of Tesla Model 3 dropped from 320,000 yuan in the past to 240,000 yuan; on January 1, 2021, Tesla Model Y officially landed in China market, and its actual price dropped by 170,000 yuan compared with the pre-selling price. Correspondingly, Tesla Model 3 immediately won a large number of new orders after the price reduction.

The high price of domestic EV brands automatically excludes the consumers with insufficient purchasing power, but fails to persuade the consumers with sufficient purchasing power, which is indeed a paradox.

If the domestic brands cannot reduce the price through reasonable ways, once the EV market is fully opened to foreign brands, the domestic brands will further lose the competitiveness and thus lose more market share in the future. 


\subsection{Safety concern}

According to an incomplete national survey, 187 electric vehicles caught fire in 2019. Indeed, these accidents involve not only foreign brand (Tesla), but also domestic brand (Nio ${ }^{[12]}$. Most fuel vehicles catch fire during the process of driving, while EVs could burn in the process of driving, charging, and even in the parking status. EVs may cause fire for various reasons, such as soaked by water, previous collision, or wire failure. These potential safety problems will also make some consumers flinch from EVs.

\section{Suggestions on the development of domestic electric vehicle industry}

\subsection{Further enrich EVs product line}

In January 2021, the sales volume of Wuling Hongguang Mini EV reached 36,762 units, far exceeding that of Tesla Model 3. The sales price of Wuling Hongguang Mini EV ranges from 28,800 yuan to 38,800 yuan, which is an entrylevel compact model. Although Wuling Hongguang Mini EV is not comparable with Tesla Model 3 at all, it at least shows that a large number of domestic consumers (including young consumers) have an urgent demand for this kind of compact EV.

In case domestic EV manufacturers just focus on medium and high-end models, they may fail to gain market advantage under the fierce market competition. Once local enterprises cannot sell their EVs on schedule, resulting in overstocking of inventory and shortage of cash flow, these local enterprises may even have problem in maintaining the regular business operation, let alone the follow-up product development.

Wuling Hongguang Mini EV has made a good start, which shows that domestic EV manufacturers should further cultivate the market, and formulate refined products according to the age, cultural preference, and income of consumers. Only through rich product lines can EV manufacturers with different market orientation find their own specific consumer groups, and finally form a virtuous circle of production-consumption-R\&D-reproduction.

\subsection{Breakthrough in the technical bottleneck of battery}

In general, the upper limit of energy density of liquid electrolyte battery used in EV industry is $300 \mathrm{wh} / \mathrm{kg}$, which will correspondingly limit the mileage of BEVs.

In addition to hydrogen fuel cell, only solid-state battery can break the energy density limit. Because solid-state battery has the characteristics of high safety, high energy density, and wide selection of cathode materials, solid-state battery is the hot spot pursued by global EV enterprises and battery enterprises.

For example, a BEV has a battery weight of $450 \mathrm{~kg}$ and its $100 \mathrm{~km}$ energy consumption is $15.12 \mathrm{kwh}$. If it is equipped with a liquid battery (the actual system energy density is $140 \mathrm{wh} / \mathrm{kg}$ ), then its theoretical mileage is:

$140 \mathrm{Wh} / \mathrm{kg} * 450 \mathrm{~kg} / 15.12 \mathrm{kWh} / 100 \mathrm{~km}=416 \mathrm{KM}$

Once the solid-state battery is equipped (the actual system energy density is $300 \mathrm{wh} / \mathrm{kg}$ ), its theoretical mileage is:

$300 \mathrm{Wh} / \mathrm{kg} * 450 \mathrm{~kg} / 15.12 \mathrm{kWh} / 100 \mathrm{~km}=890 \mathrm{KM}$

Obviously, the theoretical mileage of the same car will double after the installation of solid-state battery. At the same time, with the new battery, the $100 \mathrm{~km}$ energy consumption of the car will reduce correspondingly, which will also extend its mileage. In this case, even if the infrastructure construction of charging pile cannot be followed up in time, the longdistance driving capacity under the new battery will automatically weaken the constraints brought by the shortage of charging pile.

Therefore, local EV enterprises and battery enterprises should crack the technical bottleneck in the battery field, increase the energy density of battery, and shorten the charging time, so as to seize the market through technological revolution

When the bottleneck of battery technology is broken, more consumers will intentionally choose new energy vehicles because of economic, environmental and other factors. 


\subsection{Improve the intelligence level of EVs}

At present, some EVs are equipped with certain intelligent programs, which can bring different convenience to users combined with cloud system, such as preheating the air conditioner in the car through mobile phone, offering real-time monitoring system in the car, etc. However, these services are still passive rather than active, namely users have to send instructions to the vehicle through the mobile phone and the vehicle executes the program.

However, EV manufacturers can gradually transform the passive service of EVs into active service with the assistance of AI technology. For example, EVs can plan the most reasonable route to avoid unnecessary congestion by referring to the schedule of vehicle owners and real-time road conditions. For another example, EVs can automatically identify the speed limit in different road sections (expressway, tunnel, crosswind area, ramp, school area, etc.), automatically slow down the vehicles and feed back to the vehicle drivers, so as to avoid traffic accidents in advance. These services are extremely attractive to many consumers, such as businessmen and novice drivers.

Therefore, while improving the hardware of EVs, EV manufacturers should constantly strengthen the software upgrading, launch the human-oriented service system, and realize the human-computer interaction that EVs should have, eventually enhancing the user's sense of experience and satisfaction.

Only through a variety of ways to improve the hardware and software level of EVs can consumers really dispel their previous worries and shift from traditional fuel vehicles to EVs.

\section{References}

1. National Bureau of Statistics. Industrial Production Operation in December 2020 [Internet], [updated 2021 Jan 19]. Available from: http://www.stats.gov.cn/english/PressRelease/202101/t20210119_1812509.html.

2. Ehsani M, Ahmadi A, Fadai D. Modeling of vehicle fuel consumption and carbon dioxide emission in road transport. Renewable and Sustainable Energy Reviews 2016; 53: 1638-1648.

3. Doolan R, Muntean GM. Reducing carbon emissions by introducing electric vehicle enhanced dedicated bus lanes. 2014 IEEE Intelligent Vehicles Symposium; 2014.

4. Wilson L. Shades of green: electric cars' carbon emissions around the globe. Electricity; 2013; 5(12): 12.

5. Ahmad I, Dewan KK. Electric vehicle: a futuristic approach to reduce pollution (a case study of Delhi). World Review of Intermodal Transportation Research 2007; 1(3): 300-312.

6. $\mathrm{Lu} \mathrm{X}$. The effects of car driving and purchasing restrictions on air quality and the use of public transportation in Beijing, China. Dissertations \& Theses - Gradworks 2013.

7. Long $\mathrm{C}$, Research on the evolution and synergy of China's new energy vehicle industry policy (in Chinese) $[\mathrm{PhD}$ thesis]. 2019.

8. Continental-Corporation, 2020, Research Report on future travel trend by Continental Group in 2020 (In Chinese) [Internet]. [updated 2020 Nov 25]. Available from: https://www.sohu.com/a/447021929_236016.

9. Kou J. Acceleration of new energy vehicles in Europe: A change in the trend (In Chinese). Economy 2020; 322 (11): 76-79.

10. D1EV. The share of electric vehicles in Germany has reached $10.9 \%$ in the first 10 months and may exceed $15 \%$ in the whole year (in Chinese) [Internet]. [updated 2020 Nov 25]. Available from: https://www.d1ev.com/news/shichang/132885.

11. Electric Car Market by Technology (BEV, PHEV), by Segment (Economy, Low, Medium, Premium), by Geography (U.S., Canada, China, Japan, Netherlands, Norway, U.K., Germany, France) - Global Market Size, Share, Development, Growth, and Demand Forecast, 2013-2023 [Internet]. Prescient and Strategic Intelligence; 2018 [updated 2018 Mar]. Available from: https://www.psmarketresearch.com/market-analysis/electric-car-market.

12. Wang K. From Tesla to Weilai: spontaneous combustion becomes a lingering shadow of new energy vehicles (in Chinese). Enterprise Observer; 2019. 